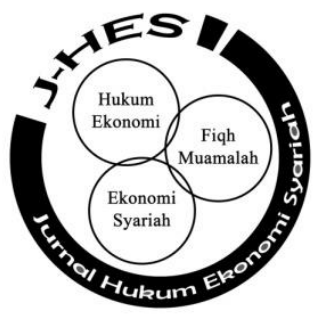

\author{
J-HES \\ Jurnal Hukum Ekonomi Syariah \\ Volume 3 | Nomor 1 | Januari-Juni 2019 \\ p-ISSN: 2549-4872 | e-ISSN: 2654-4970
}

\title{
METODE PENGAKUAN PENDAPATAN BAGI HASIL
}

\section{Erty Rospyana Rufaida ${ }^{1}$, Alamsyah ${ }^{2}$}

${ }^{1}$ Prodi Akuntansi Unismuh Makassar || email: ertyrospyana@yahoo.com

${ }^{2}$ Prodi PAI Unismuh Makassar || email: alamsyahalfaki90@gmail.com

\begin{abstract}
Abstrak.
Tujuan dari penelitian ini adalah untuk mengetahui apakah metode pengakuan pendapatan bagi hasil yang dilakukan pada PT. Bank Sulselbar Syariah Cabang Makassar telah sesuai dengan Standar Akuntansi Keuangan Syariah dengan cara membandingkan pengakuan pendapatan bagi hasil transaksi mudharabah yang dilakukan oleh PT. Bank Sulselbar Syariah Cabang makassar dengan standar akuntansi keuangan syariah No 105 Tahun 2017. Metode yang digunakan dalam penelitian ini adalah wawancaradan dokumentasi, dan metode analisis yang digunakan adalah deskriptif.Berdasarkan hasil analisis mengenai metode pengakuan pendapatan bagi hasil untuk transaksi mudhararabah yang dilakukan oleh PT. Bank Sulselbar Syariah Cabang Makassar menunjukkan bahwa metode pengakuan pendapatan bagi hasil berdasarkan gross profit atau revenue sharing. Dari hasil analisis mengenai pengakuan pendapatan bagi hasil yang dilakukan oleh PT. Bank Sulselbar Syariah Cabang Makassar menunjukkan bahwa metode pengakuan pendapatan bagi hasil yang dilakukan telah sesuai dengan standar akuntansi keuangan syariah. Alasannya karena PT. Bank Sulselbar Syariah Cabang Makassar telah menerapkan salah satu metode pengakuan yang telah diatur dalam standar akuntansi keuangan syariah No 105 Tahun 2017.
\end{abstract}

Kata Kunci: Pengakuan, Pendapatan, Mudharabah 


\begin{abstract}
.
Purpose of this study is to determine whether the method of revenue revenue recognition conducted at PT. Bank SulselbarSyariah Makassar Branch has been in accordance with Sharia Financial Accounting Standards by comparing revenue recognition for the results of mudaraba transactions conducted by PT. Bank SulselbarSyariah Branch Makassar with Islamic financial accounting standards No. 105 of 2017. The method used in this research is interview and documentation, and the method of analysis used is descriptive Based on the results of the analysis of the method of revenue sharing revenue sharing for mudararabah transactions conducted by PT. Bank SulselbarSyariah Makassar branch shows that the method of revenue revenue sharing based on gross profit or revenue sharing.From the results of the analysis of the revenue sharing of profit sharing conducted by PT. Bank SulselbarSyariah Branch Makassar indicates that the method of revenue recognition for the results made is in accordance with Islamic financial accounting standards. The reason is because PT. Bank SulselbarSyariah Makassar Branch has implemented one of the recognition methods that have been set in Islamic financial accounting standard No. 105 of 2017.
\end{abstract}

\title{
Keywords: Recognition, Income, Mudharabah
}

\section{PENDAHULUAN}

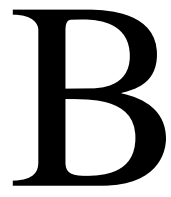

ank bagi hasil atau sering disebut Bank Syariah (Bank Islam) merupakan lembaga perbankan yang menggunakan sistem dan operasi berdasarkan prinsipprinsip hukum atau syariah Islam, seperti diatur dalam Al-Qur'an dan AlHadist. Perbankan syariah merupakan suatu sistem perbankan yang dikembangkan berdasarkan sistem syariah (hokum Islam).

Usaha pembentukkan sistem ini berangkat dari larangan Islam untuk memungut dan meminjam bedasarkan bunga yang termasuk dalam riba dan investasi untuk usaha yang dikategorikan haram, dalam hal tersebut tidak diatur dalam Bank Konvensional. Karena riba merupakan hal yang diharamkan oleh Allah SWT. Sebagaimana yang telah disebutkan dalam Q.S.Ar Rum: 39:

"Dan sesuatu riba (tambahan) yang kamu berikan agar dia bertambah pada harta manusia. Maka riba itu tidak menambah pada sisi Allah.Dan apa yang kamu berikan berupa zakat yang kamu maksudkan untuk mencapai 
keridhaan Allah, maka (yang berbuat demikian) itulah orangorang yang melipatgandakan pahalanya" (Ar-Rum: 39).

Di Indonesia pelopor perbankan syariah adalah Bank Muamalat Indonesia. Berdiri tahun 1991, bank ini diprakarsai oleh Majelis Ulama Indonesia (MUI) dan pemerintah serta dukungan dari Ikatan Cendekiawan Muslim Indonesia (ICMI) dan beberapa pengusaha muslim. Adanya perbankan syariah di Indonesia bertujuan untuk mewadahi penduduk di Negara Indonesia yang mayoritas penduduknya beragama Islam. Kehadiran bank syariah tersebut diharapkan tidak adanya kerancuan dalam proses muamalah bagi para pemeluk agama Islam, sehingga mereka terjaga dari keharaman akibat tidak adanya suatu wadah yang melayani mereka dalam bidang muamalah yang bersifat Islami.

Bank syariah menjalankan sistem perbankan sesuai dengan syariat Islam atau biasa dikenal salah satunya dengan prinsip bagi hasil. Bagi hasil yang merupakan prinsip yang diterapkan oleh bank syariah ini memberikan manfaat yang banyak bagi masyarakat. Dengan kata lain, ada keunggulan yang dimiliki sistem bagi hasil dibandingkan dengan sistem bunga (riba).

Salah satu keunggulannya adalah memberlakukan keadilan sebab keuntungan dibagi tanpa ada pihak yang dirugikan dan kerugian ditanggung bersama selama bukan disebabkan kelalaian salah satu pihak. Selain itu dalam sistem bagi hasil terdapat akad yang jelas, sebab pembagian keuntungan bukan berdasarkan pada persen bunga melainkan pembagian persentase laba seperti $30 \%$ untuk pemilik dana dan $70 \%$ untuk pengelolah dana.

Perbankan syariah tentunya memiliki banyak produk-produk yang berprinsipkan bagi hasil. Salah satunya dikenal dengan pembiayaan mudharabah yang berdasarkan prinsip bagi hasil. Dalam perhitungan Bagi Hasil, bank syariah dituntut transparan dalam memberikan informasi hasil yang diperoleh serta pembagiannya, sehingga bisa diketahui besarnya perolehan bagi hasil. Para pakar syariah Islam dan akuntansi harus mencari dasar bagi penerapan dan pengembangan standar akuntansi yang 
berbeda dengan standar akuntansi bank konvensional.

Ikatan Akuntan Indonesia (IAI) ini telah menerbitkan standar yang terkait dengan akuntansi syariah. Salah satunya adalah Pernyataan Standar Akuntansi Keuangan (PSAK) No. 105 yang mengatur tentang akuntansi mudharabah pada tahun 2007. Namun pada Awal tahun 2017, Pernyataan Standar Akuntansi Keuangan Syariah tidak lagi bergandengan dengan Pernyataan Standar Akuntansi Konvensional (PSAK). Dengan kata lain PSAK Syariah ini sudah terpisah dan berdri sendiri.

PT. Bank Sulselbar Syariah Cabang Makassar merupakan bank dengan prinsip bagi hasil yang merupakan landasan utama dalam segala operasinya, baik dalam penghimpunan maupun penyaluran dana. Salah satunya dalam sistem pembiayaan mudharabah. PT. Bank Sulselbar Syariah yang berdiri pada tahun 2007 yang bersamaan dengan tahun dicetuskannya PSAK dalam hal ini PSAK No.105 tentang akuntansi mudharabah yang kini sudah meisahkan diri menjadi PSAK Syariah No.105 Tahun 2017, tentunya sudah seharusnya mampu menerapkan sistem pencatatan pembiayaan mudharabah bersdasarkan PSAK Syariah 2017.

Berdasarkan hasil penelitian yang dilakukan Fitria Eka Permata dan Wartoyo (2017) yang meneliti mengenai analisis penerapan PSAK N0.105 pada tabungan Berjangka Mudharabah dan Pembiayaan Mudharabah bahwa tabungan berjangka sudah sesuai dengan standar namun pembiayaan masih belum sesuai standar. Penerapan pernyataan standar akuntansi keuangan dalam pengakuan pendapatan bagi hasil sering kali belum diterapkan dengan baik. Oleh karena itulah perlu dilakukan penelitian mengenai metode pengakuan pendapatan bagi hasil atas Standar Akuntansi Keuangan Syariah dari PT. Bank Sulselbar Syariah Cabang Makassar.

Berdasarkan uraian tersebut di atas maka penulis tertarik melakukan sebuah penelitian mengenai: "Analisis Metode Pengakuan Pendapatan Bagi Hasil Ditinjau Dari Standar Akuntansi 
Keuangan Syariah No. 105 Tahun 2017

Pada PT. Bank Sulselbar Syariah

Berdasarkan uraian yang telah dikemukakan di atas maka yang menjadi masalah dalam penelitian ini adalah "Apakah metode pengakuan pendapatan bagi hasil yang dilakukan pada PT. Bank Sulselbar Syariah Cabang Makassar sesuai dengan PSAK Syariah No.105 tahun 2017? “

Berdasarkan rumusan masalah yang telah disebutkan di atas maka tujuan penelitian adalah untuk mengetahui apakah metode pengakuan pendapatan bagi hasil yang dilakukan PT. Bank Sulselbar Syariah telah sesuai PSAKSyariah No.105 tahun 2017.

\section{METODE PENELITIAN}

Adapun jenis dalam penelitian ini adalah penelitian Kualitatif. Penelitian kualitatif adalah penelitian yang bertujuan untuk menguaraikan sifat atau karakteristik dari suatu fenomena tertentu.adapun dalam penelitian ini yang akan diuraikan adalah kesesuaian antara Pengakuan pendapatan bagi hasil PT.Bank Sulselbar Syariah Cabang Makassar dengan PSAK Syariah No 105 tahun 2017.

$$
\text { Fokus penelitian adalah }
$$
pemusatan konsentrasi terhadap tujuan peneitian yang diilakukan. Fokus penelitian dalam penelitian ini adalah mengamati metode pengakuan pendapatan bagi hasil mudharabah pata PT Bank Sulselbar Syariah Cabang Makassar dan kesesuaiannya terhadap PSAK Syariah No. 105 Tahun 2017. Penelitian ini dilaksanakan pada PT Bank Sulselbar Syariah Cabang Makassar yang beralamat di Jalan Dr. Ratulangi No. 16 Makassar. Sedangkan untuk melaksanakan penelitian ini dilakukan dengan waktu penelitian adalah kurang lebih 2 bulan, yaitu dimulai Bulan Mei 2018 sampai dengan Bulan Juli 2018.

Sumber data dalam penelitian adalah subyek dari mana data diperoleh. Sumber data penelitian ini dari:

a. Data primer, peneliti meneliti secara langsung pada obyek penelitian dengan cara mengadakan wawancara langsung dengan pimpinan, pegawai serta bagian keuangan dan akuntansi PT Bank Sulselbar Syariah Cabang Makassar.

b. Data sekunder, yaitu data yang diperoleh dari perusahaan melalui catatan atau dokumen seperti buku jurnal mengenai pencatatan 
pembiayaan mudharabah yang dimiliki oleh PT. Bank Sulselbar Syariah yang berhubungan dengan tujuan penelitian.

Pengumpulan data dapat dimaknai sebagai kegiatan peneliti dalam upaya mengumpulkan sejumlah data lapangan yang diperlukan untuk menjawab pertanyaan penelitian. Pengumpulan data dalam penelitian ini dilakukan sengan cara sebagai berikut:

1. Wawancara yaitu dengan melakukan komunikasi secara langsung pada pihak terkait yang dalam hal ini yaitu PT. Bank Sulselbar SyariahCabang Makassar dengan cara memberikan sejumlah pertanyaan kepada pimpinan dan pegawai PT Bank Sulselbar Syariah Cabang Makassar untuk mendapatkan data dan informasi secara jelas dan lengkap.

2. Dokumentasi, dilakukan dengan cara mengumpulkan, menyalin, melihat, serta mengevaluasi laporan dan dokumen-dokumen dari nasabah pembiayaan mudharabah yang terkait dengan objek penelitian.
Tujuan dari teknik analisis data adalah untuk mendeskripsikan data sehingga bias dipahami, lalu untuk membuat kesimpulan atau menarik sebuah kesimpulan dalam penelitian. Teknik analisis data yang digunakan dalam penelitian ini adalah dekriptifyakni suatu analisis dengan menguraikan dan menjelaskan metode pengakuan pendapatan bagi hasil pada pembiayaan mudharabah yang dilakukan oleh PT. Bank Sulselbar Syariah Cabang Makassar yang mengacu pada pernyataan Standar Akuntansi Keuangan Syariah No.105 tahun 2017.

\section{HASIL DAN PEMBAHASAN}

Analisis Metode Pengakuan Bagi Hasil Menurut PT.Bank Sulslbar Syariah Cabang Makassar

PT. Bank Sulselbar Syariah Cabang Makassar memiliki berbagai macam produk-produk jasa untuk memberikan pelayanan serta memenuhi kebutuhan transaksi perbankan yang dibutuhkan masyarakat. Penyediaan jasa tersebut dijalankan dengan menerapkan system bagi hasil. Salah satunya pembiayaan yang ditawarkan 


\section{J-HES}

Jurnal Hukum Ekonomi Syariah

Volume 3, No. 1, Januari-Juni 2019 | p-ISSN: 2549-4872 | e-ISSN: 2654-4970

kepada nasabah adalah pembiayaan mudharabah. Menurut PT. Bank Sulselbar Syariah Cabang Makassar, metode pengakuan pendapatan bagi hasil yang dilakukan oleh bank bagi hasil dari pembiayaan mudharabah diakui pada saat angsuran diterima secara tunai (cash basic).

Objek yang menjadi dalam penelitian ini adalah akad mudharabah dari nasabah PT. Bank Sulselbar Syariah adalah PT. Bank Sulselbar Syariah Cabang Makassar memberikan pinjaman kepada PT. Andry Bangunan yang memperoleh proyek bangunan sebesar Rp.1.125.121.150,- dengan jangka pekerjaan 8 bulan (JanuariAgustus 2017). Akad dalam kasus ini adalah pembiayaan Mudharabah. PT.Andry Bangunan memperoleh uang muka sebesar $20 \%$ dari nilai proyek. Sedangkan besarnya Rincian Anggaran Bangunan (RAB) adalah Rp.761.561.800,-. Ketentuan Return dari PT. Bank Sulselbar Syariah adalah $10 \%$ pertahun. sehingga dalam penelitian ini terlebih dahulu akan dilakukan perhitungan nisbah dan selanjutnya dilakukan perhitungan expected return bank yang dapat diuraikan sebagai berikut :Perhitungan Expected Return Bank

Perhitungan expected return bank dalam peneitian ini, terlebih dahulu disajikan perhitungan uang muka bangunan yang akan diterima oleh PT. ANdry Bangungan yaitu sebagai berikut:

Uang Muka $=20 \%$ x Rp.1.125.121.150,

$$
=\text { Rp.225.024.230,- }
$$

Berdasarkan hasil perhitungan uang uka, maka akan dilakukan perhitungan pembiayaan PT. Bank Sulselbar Syariah Cabang Makassar terhadap PT. Andry Bangunan yaitu sebagai berikut:

Pembiayaan Bank

$=\mathrm{RAB}-$ Uang Muka

$=$ Rp.761.561.800,- - Rp.225.024.230,-

$=$ Rp.536.537.570,-

Sedangkan laba yang diperoleh dalam pengerjaan bangunan oleh PT. Andry Bangunan adalahsebagai berikut:

Laba PT. Andry Bangunan= $=$ Rp.1.125.121.150,-

Rp.761.561.800,-

$=$ Rp.363.559.350,- 
Berdasakan hasil perhitungan laba khususnya pada PT. Andry Bangunan Maka akan dilakukan perhitungan Expected Return Bank yaitu sebagai berikut:

Expected Return $=$ Rp.536.537.570 x $\left(10 \times \frac{8}{12}\right)$ Expected Return $=$ Rp.536.537.570 x 0,067

Expected Return= Rp.35.948.017,19,-

a) Perhitungan Nisbah Bagi Hasil Mudharabah dengan Metode Revenue Sharing

Besarnya nisbah bagi hasil dengan metode revenue sharing dapat ditentuan dengan rumus :

Nisbah Bank $=\frac{\text { Expected Return Bank }}{\text { Revenue Nasabah }} \times 100 \%$

Nisbah Bank $=\frac{R p \cdot 35 \cdot 948.017,19}{R p \cdot 1 \cdot 125 \cdot 121 \cdot 150} \times 100 \%$ Nisbah Bank= 3,19\%

Kemudian besarnya nisbah PT. Andry Bangunan dapat dihitung sebagai berikut:

Nisbah PT. Andry Bangunan

$$
\begin{aligned}
& =100 \%-3,19 \% \\
& =96,81 \%
\end{aligned}
$$

Sehingga distribusi bagi hasil untuk PT. Bank Sulselbar Syariah dengan PT.Andry Bangunan dapat dihitung sebagai berikut: a) Nisbah bagi hasil PT. Bank Sulselbar Syariah

Nisbah Bagi Hasil

$=$ Rp.1.125.121.150 x 3,19\%

$=$ Rp.35.891.364,69,-

b) Nisbah bagi hasil PT. Andry bangunan

Nisbah Bagi Hasil

$=$ Rp.1.125.121.15x 96, 81\%

= Rp.1.089.229.785.31,-

Berdasarkan hasil perhitungan tersebut di atas, maka akan dapat disajikan pencatatan Mudharabah dalam pembiayaan pada PT. Andry Bangunan yang dapat dilihat melalui tabel 4.1 pada halaman berikutnya: 
Tabel 1

Pencatatan Pembiayaan Bagi Hasil Mudharabah pada PT. Bank Sulselbar Syariah Cabang Makassar

\begin{tabular}{|l|l|}
\hline \multicolumn{1}{|c|}{ Uraian } & \multicolumn{1}{|c|}{ Jumlah } \\
\hline $\begin{array}{l}\text { Jumlah pada saat penerimaan } \\
\text { dana }\end{array}$ & Kas/ Rekening Nasabah \\
& Rp.1.125.121.150 \\
& \multicolumn{1}{|c|}{ Kas BankRp.1.125.121.150 } \\
\hline $\begin{array}{l}\text { Jumlah pada saat pembayaran } \\
\text { angsuran }\end{array}$ & $\begin{array}{l}\text { Pembiayaan Mudharabah } \\
\text { Rp.536.537.570 }\end{array}$ \\
& Kas/Rek \\
\hline Jumlah pada saat penerimaan & Kas Bank \\
bagi hasil PT.Bank Sulselbar & Rp. 35.891.364,69,- \\
Syariah & Pendapatan bagi hasil \\
& Rp.35.891.364,69,- \\
\hline
\end{tabular}

Sumber: Data diambil dari PT. Bank Sulselbar Syariah Cabang Makassar

1. Analisis Metode Pengakuan prinisip bagi hasil maka dasar Pendapatan Bagi Hasil Menurut pembiayaan adalah laba bruto (Gross Standar Akuntansi Keuangan Syariah No. 105

Faktor yang menjadi penunjang dalam pengakuan pendapatan bagi hasil adalah adalanya metode pengakuan pendapatan bagi hasil. Oleh karena itu dalam melakukan pengakuan pendapatan bagi hasil maka perlu penunjang oleh metode sebagai mana yang telah diatur dalam Standar Akuntansi Keuangan Syariah No. 105.

\section{Standar Akuntansi Keuangan} Syariah No. 105 menyatakan bahwa pembagian hasil mudharabah dapat dilakukan berdasarkan prinsip bagi Profit) bukan pendapatan total usaha. Sedangkan jika berdasarkan prinisp bagi laba dasar pembiayaan laba netto (Net Profit)yaitu laba bruto dikurangi denga beban-beban yang berkaitan dengan pengelolaan modak mudharabah.

Berdasarkan hasil perhitungan di atas dalam penelitian ini metode yang digunakan adalah metode bagi hasil. Hasil perhitungan nisbahnya berdasarkan jenis pendapatan usaha (Revenue Sharing). Kemudian saat penilaian dalam perhitungan bagi hasil yang dialakukan oleh PT. Bank hasil atau bagi laba. Jika berdasarkan 
Sulselbar Syariah Cabang Makassar

dapat diuraikan sebagai berikut:

a. Saat Pumbukaan Awal

Penilaian ssat penerimaan dana

Kas/Rekening Nasabah

Rp.1.125.121.150,-

Kas Bank Rp.1.125.121.150,-

Penilaian Saat Pembukaan Awal

PembY Mudharabah Rp.536.537.570,-

Kas/Rek Nasabah Rp.

536.537.570,-

b. Saat Pendapatan Bagi Hasil

Penilaian Saat bagi hasil

Kas/Rekening Nasabah

Rp.1.089.229.785,31
Pend Mudharabah

Rp.1.089.229.785,31

Sedangkan penilaian pendapatan bagi hasil menurut SAKS 105 yaitu sebagai berikut:

Kas Bank Rp.35.891.364,69,--

Pend Mudharabah

Rp.35.891.364,69,-

Perhitungan pengakuan pendapatan bagi hasil menurut PT.Bank Sulselbar Syariah Cabang Makassar dan PSAKS No.105 akan disajikan pada tabel 4.2 pada halaman berikutnya:

Tabel 2

Perbandingan Metode Pengakuan Pendapatan Bagi Hasil Menurut PT.Bank Sulselbar Syariah Cabang Makassar dan Standar Akuntansi Keuangan Syariah No.105 Tahun 2017

\begin{tabular}{|c|c|c|}
\hline Uraian & $\begin{array}{l}\text { Menurut PT. Bank Sulselbar } \\
\text { Syariah Cabang Makassar }\end{array}$ & $\begin{array}{c}\text { Menurut PSAK Syariah } \\
\text { No.105 Tahun } 2017 \\
\end{array}$ \\
\hline 1. Metode bagi hasil & $\begin{array}{l}\text { Metode bagi hasil yang } \\
\text { diterapkan oleh PT. Bank } \\
\text { Sulselbar Syariah adalah gross } \\
\text { profit atau revenue sharing } \\
\text { (lihat perhitungan). }\end{array}$ & $\begin{array}{c}\text { Pendapatan bagi hasil usaha } \\
\text { Mudharabah dapat dilakukan } \\
\text { berdasarkan prinsip bagi hasil } \\
\text { yaitu laba bersih atau laba } \\
\text { netto. }\end{array}$ \\
\hline 2. Saat pencatatan & Kas/Rek. Nasabah & \\
\hline $\begin{array}{l}\text { A. Penerimaan } \\
\text { Dana }\end{array}$ & Kas & $\begin{array}{c}\text { Kas } \\
\text { Dana Svirkah }\end{array}$ \\
\hline B. Pembiayaan & $\begin{array}{c}\text { Pembiayaan Mudharabah } \\
\text { Kas/rek. Nasabah }\end{array}$ & temporer \\
\hline Angsuran & & $\begin{array}{c}\text { Investasi Mudharabah } \\
\text { Kas }\end{array}$ \\
\hline C. Saat bagi hasil & Pendapatan Mudharabah & $\begin{array}{c}\text { Kas Bank } \\
\text { Pend bagi Hasil Mudharabah }\end{array}$ \\
\hline
\end{tabular}

Sumber : Hasil Olah Data 


\section{J-HES}

Jurnal Hukum Ekonomi Syariah

Volume 3, No. 1, Januari-Juni 2019 | p-ISSN: 2549-4872 | e-ISSN: 2654-4970

Melihat perbandingan pengakuan pendapatan bagi hasil PT. Bank Sulselbar Syariah Cabang Makassar dengan Standar Akuntansi Keuangan Syariah menunjukkan bahwa pengakuan pendapatan bagi hasil yang dilakukan terlihat sesuai dengan pelaksanaan Standar Akuntansi Keuangan Syariah No.105 tahan 2017. Alasannya karena PT. Bank Sulselbar Syariah yaitu gross profit atau revenue sharing.Sedangkan sesuai dengan standar akuntansi keuangan yang telah dikemukakan sebelumnya Standar Akuntansi Keuangan bahwa pengakuan pendapatan bagi hasil Mudharabah dapat dilakukan berdasarkan laba bersih (gross profit) dan berdasarkan laba netto (net profit).

\section{Pembahasan}

Pembahasan dalam penelitian ini ditekankan pada metode pengakuan pendapatan bagi hasil Mudharabah khususnya pada PT. Bank Sulselbar
Syariah Cabang Makassar. Dari hasil analisis mengenai metode pengakuan pendapatan bagi hasil Mudharabah adalah metode gross profit atau revenue sharing, yang dimana konsep pengakuan pendapatan bagi hasil yang dilakukan oleh PT. Bank Sulselbar Syariah Cabang Makassar yaitu pembiayaan dilakukan revenue sharing yang diterima oleh Bank setiap bulannya.

Perhitungan bagi hasil usaha PT. Andry Bangunan yang menunjukkan nasabah PT. Bank Sulselbar Syariah Cabang Makassar menunjukkan bahwa tingkat perhitungan nisbah bagi hasil ditentukan berdasarkan tingkat perhitungan nisbah yang dilakukan dengan nasabah yang sudah ditentukan oleh PT. Bank Sulselbar Syariah Cabang Makassar. Hal ini dapat disajikan perhitungan bagi hasil PT. Bank Sulselbar Syariah Cabang Makassar pada tabel 4.3 dihalaman berikutnya: 
Tabel 3

Perbandingan Metode Pengakuan Bagi Hasil menurut PT. Bank Sulselbar Syariah Cabang Makassar dengan Standar Akuntansi Keuangan Syariah No.105 Tahun 2017.

\begin{tabular}{|l|l|}
\hline $\begin{array}{c}\text { Menurut PT. BankSulselbarSyariah } \\
\text { Cabang Makassar }\end{array}$ & \multicolumn{1}{|c|}{$\begin{array}{c}\text { Standar AkuntansiKeuangan } \\
\text { Syariah No.105 Tahun 2017 }\end{array}$} \\
\hline $\begin{array}{l}\text { Gross profit sharing / revenue sharing } \\
\text { yaitu perbandingan yang dilakukan } \\
\text { berdasarkan pendapatan yang diterima } \\
\text { oleh Bank }\end{array}$ & $\begin{array}{l}\text { Perbandingan hasil usaha dapat } \\
\text { dilakukan berdasar-kan laba bersih } \\
\text { (gross profit) dan laba netto (net } \\
\text { profit) }\end{array}$ \\
\hline
\end{tabular}

Sumber : Hasil olahan data

Kemudian dilihat dari penilaian perbandingan hasil, maka perhitungan pencatatan menurut PT. Bank Sulselbar Syariah Cabang Makassar dan Standar Akuntansi Keuangan Syariah No. 105 tahun 2017 tersebut maka dinyatakan bahwa penerapan metode pengakuan pendapatan bagi hasil Mudharabah PT.

Bank Sulselbar Syariah Cabang Makassar dapat dikatakan sesuai dengan Standar Akuntansi Keuangan Syariah No.105 Tahun 2017.

\section{KESIMPULAN}

Berdasarkan hasil analisis mengenai metode pengakuan pendapatan bag ihasil untuk Mudharabah yang dilakukan oleh PT.Bank Sulselbar Syariah menunjukkan bahwa metode pengakuan pendapatan bagi hasil berdasarkan gross profit atau revenue sharing. Sehingga Metode tang digunakan telh sesuai dengan PSAK Syariah No. 105 tahun 2017.

\section{DAFTAR PUSTAKA}

Antonio. S.M. 2011. Bank Syariah dari Teori Ke Praktik. Depok: Gema Insani Press.

Bayyin, T.A. 2017. Analisis Penerapan Psak No. 105 Dalam Transaksi Pembiayaan Mudharabah (Studi Kasus Pada Bmt Tumang Di Boyolali). Surakarta: Institut Agama Islam Negeri Surakarta.

Dosen Auntansi Blogspot. 2017. Pengertian Akuntansi Syariah. Web: https://dosenakuntansi.com/pengertian-akuntansi-syariah diakse pada tanggal 12 November 2017. 
Eny, L., Pranoto. S., dan Susilowati, E. 2013. Kajian Kesesuaian Perlakuan Akuntansi Mudharabah Dengan Psak No.105 Pada Koperasi Syariah Lamongan. Jawa Timur: Universitas Pembangunan Nasional Veteran. Volume 11, No 2: 78-90.

Halimah, Mushaf. 2009. Al-Qura'an dan Tejemahan. Bandung: Marwah.

Hery. 2011. Teori Akuntansi. Jakarta: Kencana Prenada Media Group

Huda, N. 2013. Lembaga Keuangan Syariah. Jakarta: Preanada Media.

Inna, K. 2017. Analisis Penerapan Psak No. 105 Atas Pembiayaan Mudharabah Pada Pt. Bank Muamalat Indonesia, Tbk. Kediri: Universitas Nusantara PGRI Kediri.

Kamaluddin, M.P. Analisis Kesesuaian Perlakuan Akuntansi Pembiayaan Mudharabah Dengan Psak 105 (Studi Pada Bmt Amanah Cabang Kota Kendari). Kendari: Iniversitas Halu Oleo.

Kurniasari, W.A. 2017. Evaluasi Penerapan Akuntansi Pembiayaan Mudharabah Dengan Psak No. 59 Dan Psak No. 105 Pada Kjks-Bmt Bina Ummat Sejahtera Yogyakarta. Yogyakarta: Universitas Yogyakarta.

Mafhudhoh, D. 2017. Evaluasi Penerapan Psak No.105 Terhadap Akuntansi Pembiayaan Mudharabah pada Kanindo Syari'ah Malang. Malang: UIN Maulana Malik Ibrahim Malang.

Muhammad. 2008. Manajemen Dana Bank Syariah.Yogyakarta: Ekonisia.

Nurhayati, S., dan Wasilah. 2013. Akuntansi Syariah di Indonesia. Yogyakarta: Salemba Empat.

Permata, F.E., dan Wartoyo. 2017. Analisis Penerapan PSAK No. 105 pada Tabungan Berjangka Mudharabah dan Pembiayaan Mudharabah. Cirebon: FSEI IAIN Syekh Nurjati. Volume 9, No. 1: 145-161.

Pertiwi, P.A. 2017. Penerapan Sistem Bagi Hasil dan Perlakuan Akuntansi Pembayaran Mudharabah. Surabaya: STIESIA Surabaya. Volume 6, No 7: 1-16.

Purwoko, S. 2017. Analisis Penerapan Akuntansi Pembiayaan Mudharabah Berdasarkan Psak 105 (Studi Kasus Pada Bmt Amal Muslim Wonogiri). Yogyakarta: Universitas Yogyakarta.

Sabiq, S. 2008. Fiqih Sunnah. Jakarta: Pena.

Soemitra, A. 2009. Bank dan lembaga keuangan syariah. Jakarta: Kencana

Suhendi, Hendi. 2017. Fiqh Muamalah. Depok: PT. Rajagrafindo Persada.

Turrosifa, K. 2013. Penerapan PSAK 105 Dalam Transaksi Pembayaran Mudharabah pada Bank Syariah Bukopin Cabang Sidoarjo. Surabaya: STIESIA Surabaya. Volume 2, No 8: 1-17. 